\title{
Development and testing of a 25 -item patient satisfaction scale for Black South African diabetic outpatients
}

MS Westaway, PhD, CertEd, Health and Development Research Group, Medical Research Council

P Rheeder, MBChB, MMed, FCP, MSc, Clinical Epidemiology Unit, Faculty of Health Sciences, University of Pretoria

DG van Zyl, MBChB, MMed, FCP, DipPec, Kalafong Hospital, Faculty of Health Sciences, University of Pretoria

JR Seager, PhD, Health and Development Research Group, Medical Research Council

\section{Abstract}

Although there is general agreement that patient satisfaction is an integral component of service quality, there is a paucity of South African research on reliable and valid satisfaction measures and the effects of health status on satisfaction. A 25-item patient satisfaction scale was developed and tested for evaluating the quality of health care for black diabetic outpatients. It was hypothesised that: (1) the underlying dimensions of patient satisfaction were interpersonal and organisational; and (2) patients in poor health would be less satisfied with the quality of their care than patients in good health. The questionnaire was administered to 263 black outpatients from Pretoria Academic Hospital and Kalafong Hospital. Factor analysis was conducted on the patient satisfaction scale and three factors, accounting for $71 \%$ of the variance, were extracted. The major items on Factor I were helpfulness, communication, support and consideration, representing the interpersonal dimension. Factors II and III were mainly concerned with service logistics and technical expertise, with the emphasis on waiting time, follow-up and thoroughness of examination. The three factors had excellent reliability coefficients, ranging between 0.82 (technical), 0.85 (logistics) and 0.98 (interpersonal). Multiple analyses of co-variance showed that patients in poor general health were significantly less satisfied with the logistical $(\mathrm{p}=$ $0.004)$ and technical $(\mathrm{p}=0.007)$ quality of their care than patients in good health; patients in poor mental health were significantly less satisfied with the interpersonal quality of their care

( $p=0.05$ ) than patients in good mental health. These findings provided support for both hypotheses and suggested that patients in poor health attend to different aspects of their care than patients in good health. Of more importance to clinical practice, the results endorsed the need for a multidisciplinary health team comprising nurse/ social worker (Factor I: support, communication), health service managers (Factor II: service logistics) and physician (Factor III: technical expertise) to enhance treatment

\section{Abstrak}

Ten spyte daarvan dat dit algemeen aanvaar word dat pasiëntsatisfaksie ' $n$ integrale komponent van die gehalteversekering van gesondheids-dienslewering is, is daar weinig navorsing gedoen ten opsigte van die betroubaarheid en geldigheid van metings vir satisfaksie en die effek van die gesondheidstoestand op satisfaksie in Suid-Afrika. ' $n$ Vyf en twintig (25) item pasiëntsatisfaksieskaal is ontwikkel en getoets vir die evaluering van die gehalte van gesondheidsorg op swart pasiënte met diabetes. Twee hipoteses was gestel naamlik: (1) die onderliggende dimensies van pasiëntsatisfaksie is organisatories en interpersoonlik van aard, en (2) pasiënte met swak gesondheid is minder tevrede met die gehalte van sorg as diè met goeie gesondheid. Twee honderd drie en sestig $(\mathbf{n}=$ 263) buitepasiente van die Pretoria Akademiese en Kalafong Hospitaal het die vraelys voltooi (vir ongeletterde pasiënte is ' $n$ tolk gebruik). Faktor analise van die pasiëntsatisfaksieskaal toon dat $71 \%$ van die variansie deur drie faktore verklaar kan word. Die hoof items in Faktor I wat die interpersoonlike dimensie verteenwoordig was hulpvaardigheid, kommunikasie, ondersteuning en inagneming. Faktore II en III was hoofsaaklik gemoeid met die logistiek van dienslewering en tegniese kundigheid (mediese/geneesheer). Die klem het hier geval op wagtyd, opvolg en deeglikheid van die ondersoek. Hierdie 3 faktore het uitstekende betroubaarheids koëffisiënte getoon naamlik: 0.82 (tegnies), 0.85 (logistiek) en 0.98 (interpersoonlik). Veelvuldige analise van die kovariansie toon dat pasiënte met ' $n$ swak algemene gesondheid beduidend minder tevrede was met die logistiese $(p=0.004)$ en tegniese $(p=0.007)$ aspekte van sorg, in vergelyking met pasiënte wie goeie gesondheid geniet het. Pasiënte met swak geestesgesondheid was beduidend minder tevrede met die gehalte van sorg ontvang in die interpersoonlike dimensie $(p=0.05)$ in vergelyking met pasiënte met 
outcome for diabetic patients. It is recommended that: (1) further research is conducted on this patient satisfaction scale with diverse populations in different settings to complement and validate the scale for generalised use in South Africa; (2) the scale is used to collect information on patient satisfaction before and after implementing an intervention to improve the quality of health care, and (3) measurement of health status is an essential adjunct to assessment of patient satisfaction.

\section{Key words: Empathy, communication, logistics, expertise, satisfaction, health status}

goeie geestesgesondheid. Hierdie bevindings verleen steun aan beide die gestelde hipoteses, asook dat pasiënte met swak gesondheid, ander behoeftes het ten opsigte van hulle sorg, as die met goeie gesondheid. Van meer waarde in die kliniese praktyk is dat hierdie bevindings die noodsaaklikheid van 'n multidissiplinêre gesondheidsspan bestaande uit ' $n$ verpleegkundige, maatskaplike werker (Faktor I: ondersteuning en kommunikasie), bestuurders van gesondheidsdienslewering (Faktor II: logistiek van diens) en geneesheer (Faktor III: tegniese kundigheid) beklemtoon, om die pasiënt uitkomste van die behandeling van diabetes te bevorder. Dit word aanbeveel dat: (1) verdere navorsing gedoen word om hierdie pasiëntsatisfaksieskaal te valideer vir ander bevolkingsgroepe en omstandighede, om dit meer algemeen bruikbaar te maak in Suid-Afrika, (2) die skaal gebruik word om inligting te verkry tov pasiëntsatisfaksie voor en na implementering van intervensies om gesondheidsorg te verbeter, en (3) die meting van die pasiënt se huidige gesondheidstoestand, is 'n noodsaaklike aanvullende aspek in die evaluering van pasiëntsatisfaksie.

\section{Sleutelwoorde: Empatie, kommunikasie, logistiek, kundigheid, satisfaksie, gesondheidstoestand}

\section{Introduction}

There is general agreement that patient satisfaction is an integral component of service quality (Carr-Hill 1992: 236; Sitzia and Wood 1997: 1829), since expanded definitions of health service quality make explicit mention of patient satisfaction (Fitzpatrick 1991: 888). It has been proposed that the effectiveness of health care is determined, to some degree, by satisfaction with the services provided. Support for this viewpoint has been found in studies that have reported a satisfied patient is more likely to utilise health services (Larsen and Rootman 1976:30), comply with medical treatment (Kincey, Bradshaw and Ley 1975: 564) and continue with the health provider (Baker 1990: 489).

Various studies have shown that satisfaction is related to technical and interpersonal competence, more partnership building, more immediate and positive non-verbal behaviour, more social conversation, courtesy, consideration, clear communication and information, respectful treatment, frequency of contact, length of consultation, service availability and waiting time (Hall, Roter and Katz 1988: 657; Sikosana 1994: 269; Singh, Mustapha and Haqq 1996: 255).

Single measures of satisfaction are not recommended as consumers of health care usually report high levels of satisfaction with very little variation in responses (Carr-Hill 1992: 244). Surveys in the United Kingdom (UK), Zimbabwe, Saudi Arabia and South Africa have reported that over $80 \%$ of respondents state that they are satisfied with the quality of health care they receive, despite deficiencies in manpower, skills, equipment and facilities; lengthy waiting times; and extremely short consultations (Carr-Hill 1992: 240; Community Agency for Social Enquiry 1995: 17; Mansour and Al-Osimy 1996: 312; Sikosana 1994: 270). Although these findings may reflect a reluctance to complain about services, acceptance of low standards of care, or even low levels of expectation concerning free health care; such high levels of assent, undifferentiated across populations, cast doubt upon single measures of satisfaction with health care (Carr-Hill 1992: 240; Sitzia and Wood 1997:1830).

Several self-response questionnaires have been developed and tested in the US and UK (Baker 1990: 436; Hulka, Zyzanski, Cassel and Thompson 1970: 431; Ware, Snyder, Wright and Davies 1983: 252). The problem with using self-response questionnaires in South Africa is the high proportion of functionally illiterate persons in the general population, which makes the validity of such measures problematic. A more promising approach to measuring patient satisfaction comes from Indonesia, where focus group discussions were held to identify aspects of the service that were meaningful to patient satisfaction (Bernhart, Wiadnyana, Wihardjo and Pohan 1999: 991). Fourteen factors were identified in this study. Respondents were dissatisfied with the lack of medicine, privacy during examination, the cleanliness of the facility and communication about their condition. It would appear that communication of information is the most frequent source of dissatisfaction in developing and developed countries (Carr-Hill 1992: 240). A recent South African study developed and tested a 20 -item satisfaction scale for evaluating family planning services 
(Westaway, Viljoen and Chabalala 1998: 5-6). Satisfaction was based on interpersonal factors such as friendliness and encouragement, and the organisational factors of choice, change and provision of different methods. Respondents were least satisfied with follow-up, maintenance of contact, availability of the service and waiting times; similar to previous findings on dissatisfaction (Bernhart, et al. 1999: 994; Carr-Hill 1992: 237).

Most studies on satisfaction have found that older patients report higher levels of satisfaction than younger patients (CarrHill 1992: 237; Cohen 1996: 1085; Sitzia and Wood 1997: 1835; Williams and Calnan 1991: 712). However, the relationship between age and satisfaction is confounded by health status or health-related quality of life (HRQOL). Whilst Williams and Calnan (1991: 712) found no significant relationship between health status and satisfaction in either primary or hospital care settings, Cohen (1996: 1088) reported that pain and psychosocial health status, adjusting for age, were significantly related to lower satisfaction with health care. Cohen's findings suggest that patient satisfaction is susceptible to change in response to organisational, clinical and interpersonal treatment.

A study on service quality perceptions and patient satisfaction in Bangladesh (Andaleeb 2001: 1364) found five service quality dimensions: responsiveness (caring, helpful); assurance (skilled staff, competence); communication (explanation of tests, answering questions); discipline (cleanliness of facility) and baksheesh (no services without tips). With the exception of baksheesh, many of the items used to measure service quality were similar to those used to measure patient satisfaction (Westaway, et al. 1998: 6). It would appear that the dimensions of health care quality (technical aspects of care, interpersonal relationships and the amenities of care) are virtually identical to the dimensions of patient satisfaction.

In South Africa, there is a paucity of satisfaction measures for specific populations. In addition, no local studies have investigated the relationship between health status and patient satisfaction. Therefore, a local patient satisfaction scale was developed and tested.

\section{Methods}

\section{Research Design}

A cross-sectional, analytical research design was used for the study. Based on previous research on patient satisfaction, two hypotheses were tested:

1. The underlying dimensions of patient satisfaction are interpersonal and organisational;

2. Patients in poor health are less satisfied with the interpersonal and organisational dimensions of their care than patients in good health.

\section{The Questionnaire}

A structured questionnaire, with a consent form, was designed to obtain information on: demographic variables (age, gender, years of schooling, marital status and employment status); health status (general health and mental health); and satisfaction with the interpersonal and organisational dimensions of the service.
Health status was measured by the general ( 5 items) and mental health ( 5 items) sub-scales from the 20 -item abbreviation of the Rand Medical Outcomes Study (Stewart, Hays and Ware 1988: 733-735). Scores on the sub-scales are transformed linearly to $0-100$, where 0 and 100 are assigned to the lowest and highest possible scores, respectively. The cut-off point for defining poor general health is a score of 70 or lower; for poor mental health the cut-off point is a score of 67 or lower (Stewart, Hays and Ware 1988: 728). High scores denote better general and mental health. In a recent South African study with black diabetic patients (Westaway, Viljoen and Rheeder 1999: 215), reliability coefficients ranged between 0.79 (mental health) and 0.81 (general health); in the respectable range according to Arias and de Vos (1996: 65).

Based on previous South African research (Westaway, et al., 1998), a review of the literature (Andaleeb, 2001; Bernhart, et al., 1999; Carr-Hill, 1992; Cohen, 1996; Fitzpatrick, 1991; Singh, et al., 1996; Williams and Calnan, 1991) and interviews with 20 patients, a 25 -item satisfaction scale was designed to measure the characteristics of providers and the service with regard to interpersonal and organisational dimensions of satisfaction.

Two trained black female multilingual interviewers administered the questionnaire at Pretoria Academic Hospital and Kalafong Hospital. All black persons attending Pretoria Academic Hospital and Kalafong Hospital for diabetes outpatient treatment, during the period November 1999 to July 2000, were asked to participate in the study. There were 263 patients who participated in the study; only 23 patients refused to participate due to time constraints. Ethical approval for the study was obtained from the University of Pretoria's Ethical Committee. Permission for the study was obtained from the two Hospital Superintendents. The Nursing Service Managers and staff at Pretoria Academic Hospital and Kalafong Hospital were consulted regarding the purpose of the study. Informed consent was obtained from all persons interviewed.

Descriptive statistics were the first step for data analysis. Factor analysis was conducted to ascertain the underlying dimensions of patient satisfaction. The reliability (internal consistency) of the measures was assessed (Cronbach 1970: 160-161); coefficient alpha of 0.70 was regarded as acceptable, between 0.71 and 0.80 as respectable and $>0.80$ as very good (Arias and de Vos 1996: 65; Nunnally 1978: 245-246). Multi-trait scaling was used to test the item convergent and discriminant validity of the patient satisfaction scale. This method tests whether each item in a hypothesised group is substantially related ( $\mathrm{r} \$$ 0.40 ) to the total score computed from other items in that group (item convergent validity criterion) and whether each item correlates significantly higher with its hypothesised scale than with other scales (item discriminant validity criterion). T tests and one-way analysis of variance (ANOVA) were used to examine demographic effects.

In order to test Hypothesis 2, two groups were created, based on Stewart, Hays and Ware's (1988: 728) recommended cut-off points: patients scoring \# 70 (poor health group) and patients scoring $>70$ (good health group) on the general health subscale; and patients scoring \# 67 (poor mental health group) and patients scoring $>67$ (good mental health group). Multiple analyses of co-variance, with Bonferroni t tests for multiple comparisons, were used to determine whether patients in poor 


\section{FACTORS}

Satisfaction Items

I

II

III

Friendly providers

0.84

0.29

0.26

Encouraging providers

0.84

0.32

0.25

Helpful providers

0.84

0.32

0.25

Respectful providers

0.76

0.32

0.25

Considerate providers

0.88

0.31

0.22

Providers who listen to me

0.89

0.23

0.18

Supportive providers

0.89

0.27

0.16

Providers who let me talk

0.91

0.22

0.20

Providers who let me know what is expected

0.83

0.26

0.24

Competent providers

0.82

0.31

0.30

The consistency of information

0.75

0.30

0.26

Communication understandable

0.61

0.33

0.28

Maintenance of contact

0.42

0.58

0.36

Follow-up service

0.30

0.72

0.19

Fair (equal treatment)

0.44

0.63

0.15

Available at suitable times for me

0.62

0.49

0.14

Waiting time

0.23

0.73

0.04

Availability of a seat

0.20

0.65

0.21

Availability of a toilet

0.25

0.59

0.24

Cleanliness

0.25

0.50

0.46

Privacy

0.27

0.23

0.82

Thorough examination

0.22

0.20

0.87

Cost of attendance

0.22

0.38

0.48

Medicine received

0.21

0.09

0.76

Convenience

0.45

0.45

0.47

\section{Significant loadings in bold}

health were less satisfied with the quality of their care than patients in good health.

\section{Results}

\section{Demographic Information}

The questionnaire was administered to 263 patients ( 96 from Pretoria Academic Hospital and 167 from Kalafong Hospital). There were 174 females and 89 males aged between 16 and 89 years (average age $=53.5$ years, $s d=13.9$ ). Twenty three per cent had no formal schooling, $28 \%$ some primary level schooling, $38 \%$ some high school and $11 \%$ had completed high school. The average number of years of schooling was $6.3(\mathrm{sd}=4.1)$.
Age was significantly related to schooling $(r=-0.28, p=0.01)$, indicating that older patients had limited educational opportunities.

\section{Health Status}

The average score on the general health sub-scale was 53.3 (sd $=37.7$ ) and 75.8

( $s d=24.0$ ) on the mental health sub-scale. Fifty per cent of the patients reported poor general health whereas only $28 \%$ reported poor mental health. General health and mental health were significantly related $(r=0.34, p<0.01)$. The two subscales had very good reliability coefficients (Arias and de Vos 
1996: 65), ranging between 0.88 (mental health) and 0.95 (general health); even higher than 0.79 (mental health) and 0.81 (general health) found previously by Westaway, et al. (1999: 215). Age and employment status were significantly related to general health $(p=0.01)$. As was found previously (Stewart, et al. 1988: 729; Westaway, et al. 1999: 213), older patients and those who were unemployed had poorer general health than younger patients and those who were employed.

\section{Patient Satisfaction}

The sample size of 263 patients fulfilled Boyle's (1985: 50) minimum sample size of 250 subjects and Nunnally's (1978: 421) minimum criterion for factor analysis (10 persons per item). A direct solution (principal components analysis) was the first step in analysing the 25-item scale (Nunnally 1978: 357-367). Only items with communality estimates (common factor variance) $\$ 0.30$ were taken into consideration, as items with unique
Factor II contained 7 significant loadings. The most important items were waiting time (0.73) and follow-up (0.72), applicable to service logistics. Factor III contained 3 significant loadings and appeared to be concerned with technical expertise such as thoroughness of examination $(0.87)$, privacy $(0.82)$ and medicine received (0.76), Table 1 . Two items (cost of attendance and convenience) did not meet the factor loading criterion of \$ 0.50 (Child, 1970; Nunnally, 1978). According to the factor pattern, Hypothesis 1 received considerable support, since 23 out of the 25 items had loadings $\$ .0 .50$.

The rotated coefficients were used to generate a weighted score for each of the three sub-scales (interpersonal, logistics and technical) and overall scale. Mean scores, standard deviations, range and reliability coefficients for the three sub-scales and overall scale are shown in Table 2 . The reliability coefficients were 0.98 (interpersonal), 0.85 (logistics), 0.82 (techni-

\section{Table 2: Mean Scores, Standard deviations, Range and Reliability Coefficients on the Three Patientt Satisfaction Sub-Scales and Overall Scale}

\begin{tabular}{lccccc} 
Measure & No/ltems & $\mathrm{m}$ & $\mathrm{sd}$ & Range & 定 \\
\hline Interpersonal & 13 & 48.3 & 7.5 & $12.3-52.4$ & 0.98 \\
Logistics & 7 & 19.1 & 3.3 & $9.1-22.0$ & 0.85 \\
Technical & 5 & 15.6 & 2.1 & $5.6-17.0$ & 0.82 \\
Overall scale & 25 & 85.3 & 12.0 & $31.5-93.8$ & 0.96 \\
\hline
\end{tabular}

variance (specific variance + error variance) $>0.70$ tend to be unreliable (Child 1970: 42). In order to ascertain significant loadings at the $1 \%$ level, loadings $\$ 0.50$ were examined (Child 1970: 36-38; Nunnally 1978: 423 ). All communality estimates exceeded the criterion of 0.30 and ranged between 0.47 and 0.91 . The Kaiser-Meyer-Olkin measure of sampling adequacy of the number of items was 0.92 , in the marvellous range according to Kaiser (1974: 34), and confirmed that factor analysis was the correct procedure for the data.

Based on the eigenvalues, the percentage of the total variance accounted for by the different factors and the scree plot (spatial representation of the factors), three factors, accounting for $71.1 \%$ of the total variance, were extracted. An orthogonal (VARIMAX) rotational solution was conducted to minimise the number of variables with high loadings on a factor and achieve simple structure. Factor 1 contained 13 significant loadings. The major items were: communication ( 0.91$)$, support $(0.89)$, consideration $(0.88)$, friendliness $(0.84)$, helpfulness $(0.84)$ and encouragement $(0.84)$, Table 1 . Factor I seems to represent a combination of empathy and communication (interpersonal dimension). cal) and 0.96 (overall scale). Inter-correlations among the subscales are shown in Table 3. The three sub-scales were significantly related to each other $(\mathrm{p}<0.001)$.

All items exceeded the convergent validity criterion for their scale and ranged between 0.83 and 0.94 (interpersonal), 0.58 and 0.68 (logistics) and 0.58 and 0.73 (technical). Two items (service availability and convenience) were slightly less than the discriminant validity criterion.

Multiple analyses of co-variance (MANCOVAs) were used to tease out general and mental health group effects. The adjusted mean scores (controlling for mental health) were significantly lower for the poor general health group on service logistics $(p=0.004)$ and technical expertise $(p=0.007)$. The adjusted mean scores (controlling for general health) were significantly lower for the poor mental health group on the interpersonal dimension and overall scale $(p=0.05)$, Table 4 . These findings provided full support for Hypothesis 2 , since patients in poor general and mental health were less satisfied with the interpersonal and organisational aspects of their care than patients in good general and mental health. 


\section{Discussion}

Factor analysis of the patient satisfaction scale provided substantial evidence concerning the underlying constructs of satisfaction. The interpersonal dimension, consisting of empathy and communication, was more important than the organisational dimension (logistics and technical expertise). In addition, these findings substantiated Weitzman's (1998: 385-390) model of health care quality, as the three factors included interpersonal relationships (empathy and communication), techni- care than patients in good health, providing full support for hypothesis 2, and substantiating Cohen's (1996: 1088) findings. Patients in poor general health tended to be less satisfied with the organisational aspects of their care than patients in good health. In contrast, patients in poor mental health tended to be less satisfied with the interpersonal aspect of their care than patients in good mental health. These findings suggest that patients in poor health attend to different aspects of their care than patients in good health. Therefore, measurement of health-related quality of life is essential for assessing satisfaction with the quality of care. Of major importance to clinical

\section{Table 3. Intercorrelation Matrix for the Three Patient Satisfaction Sub-Scales}

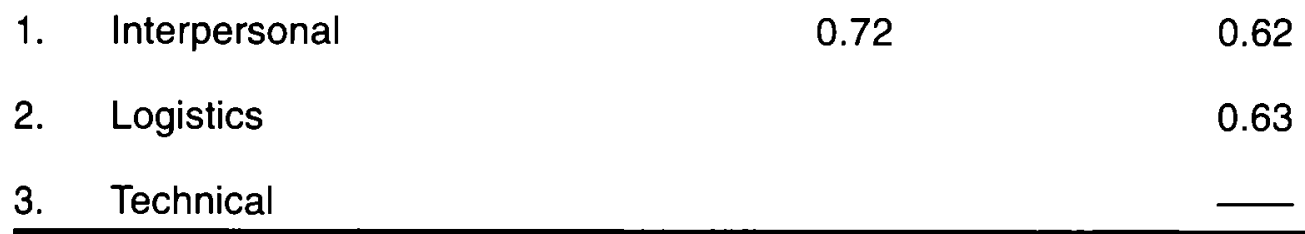

\section{Table 4. Adjusted Mean Scores (am), Standard Errors (se) and $F$ Tests for Patient Satisfaction: General Health (GH) and Mental Health (MH)}

\begin{tabular}{|c|c|c|c|c|c|c|c|c|c|c|}
\hline \multirow[b]{2}{*}{ Satisfaction Measure } & \multicolumn{2}{|c|}{ Poor GH } & \multicolumn{2}{|c|}{ Good GH } & \multirow[b]{2}{*}{$F$} & \multicolumn{2}{|c|}{ Poor $\mathrm{MH}$} & \multicolumn{2}{|c|}{ Good MH } & \multirow[b]{2}{*}{$F$} \\
\hline & am & se & $\mathrm{am}$ & se & & am & se & am & se & \\
\hline 1 & & & & & & & & & & \\
\hline Interpersonal & 48.1 & 0.7 & 48.5 & 0.7 & 0.2 & 46.8 & 0.9 & 48.9 & 0.5 & $3.8^{\star}$ \\
\hline Logistics & 18.5 & 0.3 & 19.7 & 0.3 & $8.5^{\star \star}$ & 18.7 & 0.4 & 19.3 & 0.2 & 2.1 \\
\hline Technical & 15.2 & 0.2 & 15.9 & 0.2 & $7.5^{\star \star}$ & 15.2 & 0.2 & 15.7 & 0.1 & 3.1 \\
\hline Overall scale & 84.1 & 1.0 & 86.5 & 1.1 & 2.4 & 82.9 & 1.4 & 86.2 & 0.9 & $3.9^{*}$ \\
\hline
\end{tabular}

${ }^{*} p=0.05,{ }^{* *} p<0.01$

cal aspects of care and the amenities of care, such as waiting time and the availability of a seat.

The reliability coefficients and the multi-trait analyses of the three patient satisfaction sub-scales and overall scale provided substantial evidence on the reliability and validity of the scale. Moreover, the lack of demographic effects showed that this scale held particular promise for assessing the quality of health care from a patient perspective in diverse populations and settings.

Patients in poor general and mental health were less satisfied with the interpersonal and organisational dimensions of their practice is the emphasis on interpersonal and organisational dimensions that can lead to greater satisfaction with the quality of health care. Overall findings endorse the need for a multidisciplinary health team comprising nurse/social worker (Factor I: support, communication); health service managers (Factor II: service logistics); and physician (Factor III: technical expertise) to enhance treatment outcome for diabetic patients.

It is recommended that: (1) further research is conducted on this patient satisfaction scale with diverse populations in dif- 
ferent settings to complement and validate the scale for generalised use in South Africa; (2) the scale is used to collect information on patient satisfaction before and after implementing an intervention to improve the quality of health care, and (3) measurement of health status is an essential adjunct to assessment of patient satisfaction.

\section{Acknowledgements}

We wish to thank the patients for participating in the study; Drs Elaine Pretorius and Katherine Kroeger for assistance with patient recruitment; the interviewers for their commitment to the patients and the study; Nurse Golele for data coding, capture and cleaning; Piet Becker for statistical advice; the Hospital Superintendents and staff for supporting the study; and Health Systems Trust for their grant support.

\section{References}

ANDALEEB, SS 2001: Service quality perceptions and patient satisfaction: a study of hospitals in developing countries. Social Science and Medicine. 52: 1359-1370.

ARIAS, E \& de VOS, S 1996: Using housing items to indicate socioeconomic status: Latin America. Social Indicators Research. 38: 53-80.

BAKER, R 1990: Development of a questionnaire to assess patients' satisfaction with consultants in general practice. British Journal of General Practice. 40: 487-490.

BERNHART, MH; WIADNYANA, IGP; WIHARDJO, H \& POHAN, 1 1999: Patient satisfaction in developing countries. Social Science and Medicine. 48: 989-996.

BOYLE, GJ 1985: Self-report measures of depression: some psychometric considerations. British Journal of Clinical Psychology. 24: 45-59.

CARR-HILL, RA 1992: The measurement of patient satisfaction. Joumal of Public Health \& Medicine. 14: 236-249.

CHILD, D 1970: The essentials of factor analysis. London: Holt, Rinehart \& Winston, 36-38, 42.

COHEN, G 1996: Age and health status in a patient satisfaction survey. Social Science and Medicine 42: 1085-1093.

COMMUNTTY AGENCY FOR SOCIAL ENQUTRY,(CASE) October 1995: A national household survey of health inequalities in South Africa. Menlo Park, California: The Henry J. Kaiser Family Foundation.

CRONBACH, LJ 1970: Essentials of psychological testing, 3rd ed. New York: Harper \& Row, 160-161.

FITZPATRICK, R 1991: Surveys of patient satisfaction: I Important general considerations. British Medical Journal. 302: 887-889.
HALL, JA; ROTER, DL \& KATZ, NR 1988: Meta-analysis of correlates of provider behavior in medical encounters. Medical Care. 26: 657-675.

HULKA, BS; ZYZANSKI,SJ; CASSEL, JC \& THOMPSON, SJ 1970: Scale for the measurement of attitudes toward physicians and primary medical care. Medical Care. 8: 429-436.

KAISER, HF 1974: An index of factorial simplicity. Psvchometrika. 39: 31-36.

KINCEY, JA; BRADSHAW, PW \& LEY, P 1975: Patient satisfaction and reported acceptance of advice in general practice. Journal of the Royal College of General Practice. 25: 558-566.

LARSEN, DE \& ROOTMAN, R 1976: Physicians' role performance and patient satisfaction. Social Science and Medicine. 10:29-32.

MANSOUR, AA \& AL-OSIMY, M 1996: A study of health centers in Saudi Arabia. International Journal of Nursing Studies, 33: 309-315.

NUNNALLY,JC 1978: Psychometric theory, 2nd ed. New York: McGraw-Hill, 245-246, 357-367,421, 423.

SIKOSANA, PL 1994: An evaluation of the quality of antenatal care at rural health centres in Matabeleland North Province. Central African Journal of Medicine. 40: 268-272.

SINGH, H; MUSTAPHA, N \& HAQQ ED 1996: Patient satisfaction at health centres in Trinidad and Tobago. Public Health. 110:251-255.

SITZIA, J \& WOOD, N 1997: Patient satisfaction: a review of issues and concepts. Social Science and Medicine. 45: 18291843.

STEWART, AL; HAYS, RD \& WARE JE 1988: The MOS Short-Form General Health Survey: reliability and validity in a patient population. Medical Care. 26: 724-735.

WARE, JE; SNYDER, MK; WRIGHT, WR \& DAVIES, AR 1983: Defining and measuring patient satisfaction with medical care. Evaluation and Program Planning, 6: 247-263.

WEITZMAN, BC 1998: Improving quality of care. (In: Kovner, AR \& Jonas, S Eds. 1998: Health care delivery in the United States, 6th ed. pp 370-400.

WESTAWAY, MS; VILJOEN, E \& CHABALALA, HP 1998: Satisfaction with family planning services: interpersonal and organisational dimensions. Curationis. 21:3-7.

WESTAWAY, MS; VILJOEN, E \& RHEEDER, P 1999: Does blood glucose control affect the health-related quality of life (HRQOL) of urban black South African type 2 diabetes mellitus patients? Diabetes Research 34: 209-217.

WILLIAMS, SJ \& CALNAN, M 1991: Convergence and divergence: assessing criteria of consumer satisfaction across 
